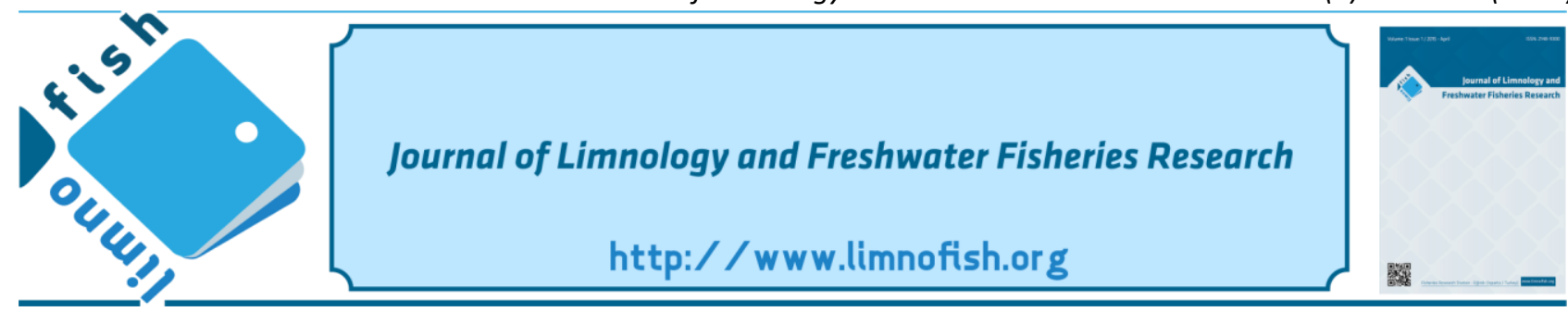

\title{
Chlorella sorokiniana' nın İzolasyonu, Moleküler Tanılanması, Fototrofik, Miksotrofik ve Heterotrofik Üretimi
}

\author{
Döndü YALÇIN BİNGÜL ${ }^{1}$ (D), Zeliha DEMİREL ${ }^{2}$ (D) , Meltem CONK DALAY 2* (D) \\ ${ }^{1}$ Aydın Adnan Menderes Üniversitesi, Fen Fakültesi, Biyoloji Bölümü, Aydın, Türkiye \\ ${ }^{2}$ Ege Üniversitesi, Mühendislik Fakültesi, Biyomühendislik Bölümü, İzmir, Türkiye
}

\section{$\ddot{O} Z$}

İzmir'in Gümüldür bölgesinden alınan su örneğinde, seyreltme ve dökme plaka yöntemleri kullanılarak mikroalg izolasyonu yapılmıștır. Ișık mikroskobuyla morfolojik olarak değerlendirilen türün Chlorella sp. olduğu saptanmıştır. Moleküler yöntemlerle mikroalg DNA's1 izole edilerek 16S ve 18S rRNA gen bölgeleri PCR'da çoğaltılmıştır. Bu dizinin sekanslanması ve filogenetik olarak değerlendirilmesi sonucu Chlorella sorokiniana olduğu belirlenmiştir. Aksenik C. sorokiniana elde etmek için santrifüj ile yıkama, antibiyotik ile muamele, agar ortamında büyütme ve tek hücre izolasyonu gibi farklı yöntemler kullanılarak aksenikleştirme işleminden başarılı sonuçlar elde edilmiştir. Fototrofik $C$. sorokiniana' dan elde edilen biyokütle $\left(0,19 \mathrm{~g} \mathrm{~L}^{-1}\right)$ ve spesifik büyüme hızı $\left(0,78\right.$ gün $\left.^{-1}\right)$, miksotrofik $C$. sorokiniana' dan elde edilen biyokütle $\left(0,31 \mathrm{~g} \mathrm{~L}^{-1}\right)$ ve spesifik büyüme hızı $\left(1,3\right.$ gün $\left.^{-1}\right)$, heterotrofik $C$. sorokiniana' dan elde edilen biyokütle $\left(0,6 \mathrm{~g} \mathrm{~L}^{-1}\right)$ ve spesifik büyüme hızı $\left(2,52\right.$ gün $\left.^{-1}\right)$ olarak belirlenmiştir. Elde edilen bulgulara göre aksenik mikroalg $C$. sorokiniana' nın farklı üretim koşullarındaki biyokütle verimliliği şu şeklide sıralanabilir: heterotrofi $>$ miksotrofi $>$ fototrofi.

Anahtar kelimeler: Chlorella sorokiniana, moleküler tanılama, fototrofi, miksotrofi, heterotrofi

\section{MAKALE BILGISI}

ARAŞTIRMA MAKALESi
$\begin{array}{ll}\text { Geliş } & : 19.03 .2020 \\ \text { Düzeltme } & : 05.01 .2021 \\ \text { Kabul } & : 10.01 .2021 \\ \text { Yayım } & : 26.08 .2021\end{array}$

DOI:10.17216/LimnoFish.703234

\section{* SORUMLU YAZAR}

meltem.dalay@ege.edu.tr

Tel : +902323884955

Isolation, Molecular Identification, Phototrophic, Mixotrophic and Heterotrophic Production of Chlorella sorokiniana

\begin{abstract}
Microalgae was isolated using dilution and pouring plate method from the sea water sample taken from the Gumuldur region of Izmir. The species was identified as Chlorella sp. through morphologic evaluation under light microscope. Microalgae DNA was isolated through molecular methods and $16 \mathrm{~S}$ and $18 \mathrm{~S}$ rRNA gene regions were amplified by means of PCR. As a result of sequencing and phylogenetic evaluation of the gene regions, it was determined that the microalgae was Chlorella sorokiniana. Different methods such as centrifuge washing, antibiotic treatment, growth on agar and single cell isolation used to obtain axenic C. sorokiniana yielded successful results. Biomass and specific growth rate of phototrophic C. sorokiniana $\left(0.19 \mathrm{~g} \mathrm{~L}^{-1}\right.$ and 0.78 days $^{-1}$, respectively), mixotrophic $C$. sorokiniana $\left(0.31 \mathrm{~g} \mathrm{~L}^{-1}\right.$ and 1.3 days $^{-1}$, respectively) and heterotrophic $C$. sorokiniana $\left(0.6 \mathrm{~g} \mathrm{~L}^{-1}\right.$ and 2.52 days $^{-1}$, respectively) were determined. According to the findings obtained, the biomass productivity of axenic C. sorokiniana under different culture conditions can be ordered as: heterotrophy > mixotrophy > phototrophy.
\end{abstract}

Keywords: Chlorella sorokiniana, molecular identification, phototrophy, mixotrophy, heterotrophy

\section{Alıntılama}

Yalçın Bingül D, Demirel Z, Conk Dalay M. 2021. Chlorella sorokiniana’ nın İzolasyonu, Moleküler Tanılanması, Fototrofik, Miksotrofik ve Heterotrofik Üretimi. LimnoFish. 7(2): 128-137. doi: 10.17216/LimnoFish.703234

\section{Giriş}

Dünyada 30.000' den fazla mikroalg türü vardır ve bunlardan sadece 100' e yakını ekonomik açıdan değerlendirilmektedir (Sasson 1997; Borowitzka 1992). Mikroalgler, gelişmiş ülkelerde, pigmentler gibi yüksek katma değerli bileşiklerin elde edilmesinde, gıda endüstrisi ve sağlık amaçlı gıda üretiminde; gelişmekte olan ülkelerde ise atık arıtımı ve proteince zengin gida ve yem katkıs1 üretimini birleştiren küçük ölçekli projeler ile büyük ölçekli atık su arıtımında kullanilırlar (Sasson 1997). Mikroalglerin kimyasal komposizyonu türe ve kültür koşullarına göre değişmekle (Zhu 2015) birlikte genellikle 
protein (\%10-63) (Becker 2007; Miao ve Wu 2004) karbonhidrat (\%6-57) (Yeh vd. 2010; Hariskos ve Posten 2014) ve lipitler (\%4-55) (Becker 2007; Miao ve Wu 2004) gibi primer metabolitlerden oluşur.

Mikroalgler, genellikle ototrofik olarak yaşarlar ve fotosentez yaparak, karbondioksit, su ve güneş 1şığını biyokütleye dönüştürürler (Pragya vd. 2013; Zhu 2015). Fakat bazı mikroalg türleri enerji ve karbon kaynağı olarak organik substratları kullanarak heterotrofik ve miksotrofik olarak da gelişebilirler (Chen 1996; Lee 2001). Örneğin, Chlorella vulgaris (Mitra vd. 2012), Chlorella sorokiniana (Wang vd. 2012), Chlorella zofingiensis (Liu vd. 2011), Haematococcus pluvialis (Kobayashi vd. 1992), Spirulina platensis (Marquez vd. 1993) ve Botryococcus braunii (Zhang vd. 2011) ototrofik, heterotrofik ve miksotrofik şartlar altında gelişebilmektedir (Kim vd. 2013).

Heterotrofik kültürler, 1şıksız koşullar altında tek karbon kaynağı olarak organik karbonu kullanırlar. Miksotrofik kültürler ise ototrofik ve heterotrofik beslenmenin birleşimi bir karakteristik gösterirler, karbon kaynağ1 olarak hem organik hem de inorganik karbonu kullanırlar (Kim vd. 2013; Chen vd. 2011). Heterotrofik ve miksotrofik büyümede genellikle organik karbon kaynağı olarak glikoz, galaktoz, mannoz, fruktoz, sükroz ve laktoz kullanılmaktadır (Abreu vd. 2012). Organik karbondan elde edilen enerji, hücre sentezinde kullanılırken, 1şık enerjisinden dönüştürülen kimyasal enerji depolanmaktadır (Chojnacka ve Marquez-Rocha 2004). Mikroalg kültür koşullarına bağlı enerji ve karbon kaynakları ve metabolit yolağına göre $\mathrm{pH}$ değişimi Tablo $1^{\prime}$ de gösterilmektedir.

Tablo 1. Ototrofik, heterotrofik ve miksotrofik şartlarda enerji ve karbon kaynağı, pH değişiminin özeti

Table 1. Summary of energy and carbon source, $\mathrm{pH}$ change in autotrophic, heterotrophic and myxotrophic conditions

\begin{tabular}{cccc} 
Kültür tipi & Enerji kaynağı & Karbon kaynağı & Metabolizma \\
\hline Ototrof & Işık & İnorganik & $\mathrm{H}_{2} \mathrm{O}+\mathrm{HCO}_{3}{ }^{-} \rightarrow \mathrm{C}($ biyokütle $)+1 / 2 \mathrm{O}_{2}+3 \mathrm{OH}^{-}: \mathrm{pH}_{\text {artar. }}$ \\
Heterotrof & Organik & Organik & $(1+a) \mathrm{CH}_{2} \mathrm{O}+\mathrm{O}_{2} \rightarrow \mathrm{C}($ biyokütle $)+a \mathrm{CO} 2+(1+a) \mathrm{H}_{2} \mathrm{O}: \mathrm{pH}$ azalır. \\
Miksotrof & Işık ve organik & $\begin{array}{c}\text { İnorganik ve } \\
\text { organik }\end{array}$ & $b \mathrm{HCO}_{3}+c \mathrm{CH}_{2} \mathrm{O} \rightarrow(\mathrm{b}+(\mathrm{c}-\mathrm{a})) \mathrm{C}($ biyokütle $)+3 \mathrm{OH}^{-}+\mathrm{aCO}_{2}: \mathrm{pH}^{\text {değişkendir. }}$
\end{tabular}

Ototrofik mikroalgler, inorganik karbonu kullanırlar ve hidroksil üreterek pH'ı yükseltirler. Heterotrofik mikroalgler, organik karbonu kullanırlar ve $\mathrm{CO}_{2}$ üreterek $\mathrm{pH}$ '1 düşürürler. Miksotrofik mikroalgler eş zamanlı olarak hem organik hem de inorganik karbonu kullanırlar ve $\mathrm{pH}$ değeri değişkenlik göstermektedir. (Elcik ve Çakmakçı 2017).

Literatür taraması sonucu ototrofik, heterotrofik ve miksotrofik mikroalg büyüme hızı sirasiyla 0,2-0,7 gün ${ }^{-1}, 0,4-0,9$ gün $^{-1}$ ve 0,3-0,6 gün ${ }^{-1}$ arasında değişmektedir. Heterotrofik mikroalglerin büyüme hızının, diğer kültür tipleriyle kıyaslandığında daha yüksek olduğu görülmektedir. Heterotrofik büyüme şekli özellikle değerli kimyasalların ve farmasötiklerin üretimi için uygundur.

Yapılan bu çalışmada, yerel bir kaynaktan izole edilen örneğin morfolojik ve moleküler yöntemler kullanılarak tür teşhisi yapılmış ve Chlorella sorokiniana olduğu saptanmıştır. Biyoteknolojik olarak önemli bir tür olan $C$. sorokiniana fototrofik, miksotrofik ve heterotrofik üretim potansiyeli açısından değerlendirilmiştir. Sonuç olarak en verimli üretim yöntemi heterotrofik şartlar altında sağlanmıştır.

\section{Materyal ve Metot}

$\mathrm{Bu}$ çalışmada kullanılan Chlorella sorokiniana İzmir'in Gümüldür bölgesinden izole edilmiştir. ESW (Enriched Seawater) ortamı kullanılarak türün kültürü yapılmıştır (Tablo 2) (Provasoli 1963,1968; McLachlan 1973).

ESW ortamı hazırlamak için 1L steril edilmiş deniz suyuna $20 \mathrm{~mL} / \mathrm{L}$ zenginleştirilmiş çözelti (Enrichment Sewater Solution) eklenerek pH 7,8 olarak ayarlanmıştır. Heterotrofik ve miksotrofik kültürlerde karbon kaynağı olarak glukoz (3 g/L) kullanılmıştır.

Kültürü yapılan mikroalg örneği düzenli aralıklarla kültür ortamları ile seyreltilerek ve dökme plaka yöntemi kullanılarak izole edilmiştir. Kültüre alınan örnek agar $(\% 1,5)$ besiyerine ve yatık agara çizgi ekim metodu uygulanarak saklanmıştır (Sukatar 2002). Saflaştırılan tür, $25^{\circ} \mathrm{C}$ 'de ve sürekli aydinlatmada (Wiselight marka $24 \mathrm{~W}$ day-light) steril agar üzerinde inkübasyona bırakılmıştır. 
Tablo 2. ESW (Zenginleştirilmiş Deniz Suyu) ortamının hazırlanışı

Table 2. Preparation of ESW (Enriched Seawater) medium

\begin{tabular}{lll}
\hline Kimyasal & Miktar & Son konsantrasyon \\
\hline $\mathrm{NaNO}_{3}$ & $2,35 \mathrm{~g} / \mathrm{L}$ & $34 \mathrm{mM}$ \\
$\mathrm{Na}_{2}$ gliserofosfat. $5 \mathrm{H}_{2} \mathrm{O}$ & $0,35 \mathrm{~g} / \mathrm{L}$ & $1,6 \mathrm{mM}$ \\
ES Fe Çözeltisi & $163 \mathrm{~mL} / \mathrm{L}$ & \\
P-II Metal Çözeltisi & $163 \mathrm{~mL} / \mathrm{L}$ & \\
Tris & $1 \mathrm{~g} / \mathrm{L}$ & \\
Vitamin B12 & $1,5 \mathrm{~mL} / \mathrm{L}$ & \\
Biotin Vitamin Çözeltisi & $1,5 \mathrm{~mL} / \mathrm{L}$ & \\
Tiamin Vitamin Çözeltisi & $1,5 \mathrm{~mL} / \mathrm{L}$ & Son konsantrasyon \\
\hline ES Fe Çözeltisi & & $1,8 \mathrm{mM}$ \\
\hline Kimyasal & Miktar & $1,6 \mathrm{mM}$ \\
\hline FeCl $6 \mathrm{H}_{2} \mathrm{O}$ & $0,35 \mathrm{~g} / 500 \mathrm{~mL}$ & \\
$\mathrm{Na}_{2} \mathrm{EDTA}_{2} 2 \mathrm{H}_{2} \mathrm{O}$ & $0,30 \mathrm{~g} / 500 \mathrm{~mL}$ & Son konsantrasyon \\
\hline P-II Metal Çözeltisi & & $0,27 \mathrm{mM}$ \\
\hline Kimyasal & Miktar & $1,8 \mathrm{mM}$ \\
\hline $\mathrm{Na}_{2} \mathrm{EDTA}_{2} 2 \mathrm{H}_{2} \mathrm{O}$ & $0,1 \mathrm{~g} / 100 \mathrm{~mL}$ & $0,097 \mathrm{mM}$ \\
$\mathrm{H}_{3} \mathrm{BO}_{3}$ & $0,114 \mathrm{~g} / 100 \mathrm{~mL}$ & $0,007 \mathrm{mM}$ \\
$\mathrm{MnSO}_{4} \cdot \mathrm{H}_{2} \mathrm{O}$ & $16,4 \mathrm{mg} / 100 \mathrm{~mL}$ & $0,002 \mathrm{mM}$ \\
$\mathrm{ZnSO}_{4} \cdot 7 \mathrm{H}_{2} \mathrm{O}$ & $2,2 \mathrm{mg} / 100 \mathrm{~mL}$ & \\
$\mathrm{CoCl}_{2} \cdot 6 \mathrm{H}_{2} \mathrm{O}$ & $0,48 \mathrm{mg} / 100 \mathrm{~mL}$ & \\
\hline Vitamin Çözeltisi & & \\
\hline Kimyasal & Miktar & \\
\hline Vitamin B12 & $0,0135 \mathrm{~g} / 100 \mathrm{~mL}$ & \\
Biotin $_{\text {Tiamin }}$ & $0,0025 \mathrm{~g} / 100 \mathrm{~mL}$ & \\
\hline
\end{tabular}

Saflaştırılan mikroalgin morfolojik tayini için 1şık mikroskobu (Olympus CH40) kullanılmıştır. Moleküler tür tayini için mikroalg DNA'ları, ZRFungal/Bacterial DNA Kiti kullanılarak saflaştırılmıştır. 50-100 mg agar yüzeyinden alınan mikroalg hücresi $200 \mu \mathrm{l}$ ultra saf su içerisinde porselen boncukların olduğu tüpe alınarak üzerine lizis solüsyonu eklendikten sonra hücrelerin parçalanması için maksimum hızda $5 \mathrm{dk}$ vorteks yapılmıştır. Lizis tüpü $10.000 \mathrm{x}$ g de $1 \mathrm{dk}$ santrifüjlendikten sonra Spin filter tüpüne aktarılan süpernatant $7.000 \mathrm{rpm}$ de $1 \mathrm{dk}$ santrifüj edilmiş ve DNA Binding Tamponu eklenerek toplama tüpüne ilave edilmiştir. Zymo-Spin Column toplama tüpü içerisine yerleştirilen ve $10.000 \times \mathrm{g} 1 \mathrm{dk}$ santrifüj edilen Zymo-Spin Column yeni toplama tüpü içerisine yerleştirilir ve filtre üzerine DNA Pre-Wash Tamponu ilave edilip, $10.000 \times \mathrm{g} 1 \mathrm{dk}$ santrifüjlendikten sonra $500 \mu \mathrm{l}$ DNA Wash Tamponu ilave edilir ve sonra tekrar aynı şekilde santrifüjlenir. Zymo-Spin Column $1,5 \mathrm{ml}$ steril ependorf içerisine dikkatlice yerleştirilir ve üzerine DNA Elution Tamponu ilave edilerek $10.000 \times \mathrm{g} 30$ saniye santrifüjlenerek filtrede tutulan DNA'nın ependorf içerisine toplanması sağlanmıştır. Mikroalg genlerinin spesifik bölgelerinin PCR (HelixAmp $^{\mathrm{TM}}$ HyberSense DNA polimeraz
(Nanohelix) kiti) yöntemiyle amplifikasyonları için mikroalglerin gen bölgelerine özgül primer dizileri 16S rRNA 359F (5'-GGG GAA TYT TCC GCA ATG GG-3') -781R(a) (5'-GAC TAC TGG GGT ATC TAA TCC CAT T-3') ve (b) (5'-GAC TAC AGG GGT ATC TAA TCC CTT T-3') ve ayrica $18 \mathrm{~S}$ ribozomal küçük alt birim rRNA SSU-F (5'-TGG TTG ATC CTG CCA GTA G-3', SSU-R; 5'-TGA TCC TTC CGC AGG TTC AC-3') kullanılmıştır (Nübel, 1997; Boutte vd. 2006; Yildırım vd. 2014). PCR cihazı HelixAmp ${ }^{\mathrm{TM}}$ HyberSense DNA polimeraz kiti kullanılarak; ilk denatürasyon adım $195{ }^{\circ} \mathrm{C}$ de $2 \mathrm{dk}$ olarak tek adımda başlatılmış ve 35 döngü $95{ }^{\circ} \mathrm{C}$ de $30 \mathrm{~s}$, bağlanma 1sıs1 (359F-781R (a, b)) için $65^{\circ} \mathrm{C}$ ve SSUF-R için $54{ }^{\circ} \mathrm{C}$ sicaklıkta $40 \mathrm{~s}$ de, $72{ }^{\circ} \mathrm{C}$ de $40 \mathrm{~s}$ den sonra son uzama adımı, 1 döngü olarak $72{ }^{\circ} \mathrm{C}$ de $5 \mathrm{dk}$ olacak şekilde ayarlanmıştır. DNA ve PCR ürünleri $\% 1$ agaroz jel elektroforezin de 1x-Tris-borik asit-EDTA (TBE) tamponu içerisinde $5 \mathrm{~V} / \mathrm{cm}$ yürütüldükten sonra SYBR safe ile boyanan jel UV görüntüleme cihazı ile görüntülenmiştir.

PCR sonuçlarının dizi analizi İzmir İleri Teknoloji Enstitüsü Biyoteknoloji ve Biyomühendislik Merkezi Araştırma Laboratuarı' nda (ABI3130XL, 16 KAPÍLLER SİSTEM) 
yapılmıştır. Sonuçlar NCBI-Blast programı yardımıyla değerlendirilmiştir.

Hücre konsantrasyonunu tespit etmek ve büyüme grafiklerini çıkarabilmek için gün aşırı örnek alınmıştır. 2,5 mL mikroalg örneğinin $2 \mathrm{~mL}$ 'si optik yoğunluk (OD) ölçümünde ve geri kalanı Neubauer sayım kamarası yardımıyla mikroskop altında sayılmıştır. C. sorokiniana'nın OD değeri $600 \mathrm{~nm}$ 'de Ultraspec 1100 pro markalı spektrofotometre kullanılarak ölçülmüştür.

Spesifik büyüme hızlarının ve ikilenme sürelerinin hesaplamaları Becker (1995)' in formülüne göre yapılmıştır.

$$
\mu=\frac{\ln x 2-\ln x 1}{\Delta t}
$$

$\mu$, spesifik büyüme hızı; x2, t2 zamanındaki hücre konsantrasyonu; $\mathrm{x} 1$, t1 zamanındaki hücre konsantrasyonu; $\Delta \mathrm{t}=\mathrm{t} 2$-t 1 , DT, ikilenme süresi

$$
D T=\frac{\ln 2}{\mu}
$$

Aksenik kültür izolasyonu için $100 \mu \mathrm{g}$. $\mathrm{mL}^{-1}$ ampisilin, $25 \mu \mathrm{g}$. $\mathrm{mL}^{-1}$ kanamisin, $25 \mu \mathrm{g} . \mathrm{mL}^{-1}$ streptomisin ve $25 \mu \mathrm{g}$. $\mathrm{mL}^{-1}$ gentamisin içeren antibiyotik kokteyli $0,2 \mu \mathrm{m}$ steril filtreden geçirilerek kullanılmıştır. Antibiyotik uygulamasından önce $C$. sorokiniana örneği $4500 \mathrm{rpm}$ ' de $5 \mathrm{dk}$ süreyle santrifüj işlemiyle steril kültür ortamı ile 3 kere yıkanmıştır. İşlem sonrasinda kalan pellet, $5 \mathrm{ml}$ taze ESW ortamiyla homojenize edilerek $200 \mu \mathrm{l}$ antibiyotik kokteyli eklenmiş ve 24 saat bekletilmiştir. Kültür taze ESW ortamına alınarak antibiyotiksiz agara çizgi ekim yöntemiyle transfer edilmiştir. Santrifüj işlemiyle bakteri sayısı azaltılan kültür aynı zamanda $5 \mathrm{ml}$ taze ESW ortamına transfer edilmiş ve $25 \mu$ lörnek antibiyotikli agar üzerine çizgi ekim yöntemiyle ekilmiştir. Hem antibiyotikli hem de antibiyotiksiz agar üzerinde oluşan mikroalg kolonileri steril edilmiş kürdan yardımıyla teker teker toplanıp $3 \mathrm{~mL}$ steril sıvı ortam içeren test tüplerine alınmıştır. Yoğun 1şık altında inkübatörde inkübasyona bırakılmıştır.

Yoğunlaşan kültürlerin akseniklik testi için 100 $\mu \mathrm{L}$ örnek "Nutrient Agar" üzerine yayma ekim yöntemiyle transfer edilerek $30^{\circ} \mathrm{C}$ ' de $2-3$ günlük inkübasyona bırakılmıştır.

\section{Bulgular}

Chlorophyta grubunun üyeleri genellikle 2-10 $\mu \mathrm{m}$ çapındaki boyutlara sahiptir. Hücreler küresel ya da elipsoid şekillidir. Ayrıca hücrelerinde tek nukleus ve bir kromatofor vardır, tek tek olduğu gibi koloni de meydana getirebilirler. Vejatatif safhada kamçıları olmayan, hareketsiz alglerdir.
Kloroplastlarında bulunan pirenoidlerde nişasta oluştururlar. Nişastayı sitoplazma yerine kloroplastlarında oluşturdukları için diğer alg gruplarından ayrilırlar. $\mathrm{Bu}$ grup üyeleri hem denizlerde hem de tatlı sularda yayılış gösterir (Güner ve Aysel 1991).

Mikroalg taksonunun siniflandirilmasinda AlgaeBase web sitesi temel alınmıştır (AlgaeBase 2021).

$\begin{array}{ll}\text { Domain } & \text { : Eukaryota } \\ \text { Kingdom } & : \text { Plantae } \\ \text { Subkingdom } & \text { : Viridiplantae } \\ \text { Infrakingdom } & \text { : Chlorophyta infrakingdom } \\ \text { Phylum } & \text { : Chlorophyta } \\ \text { Subphylum } & \text { : Chlorophytina } \\ \text { Class } & : \text { Trebouxiophyceae } \\ \text { Order } & \text { : Chlorellales } \\ \text { Family } & : \text { Chlorellaceae } \\ \text { Genus } & : \text { Chlorella }\end{array}$

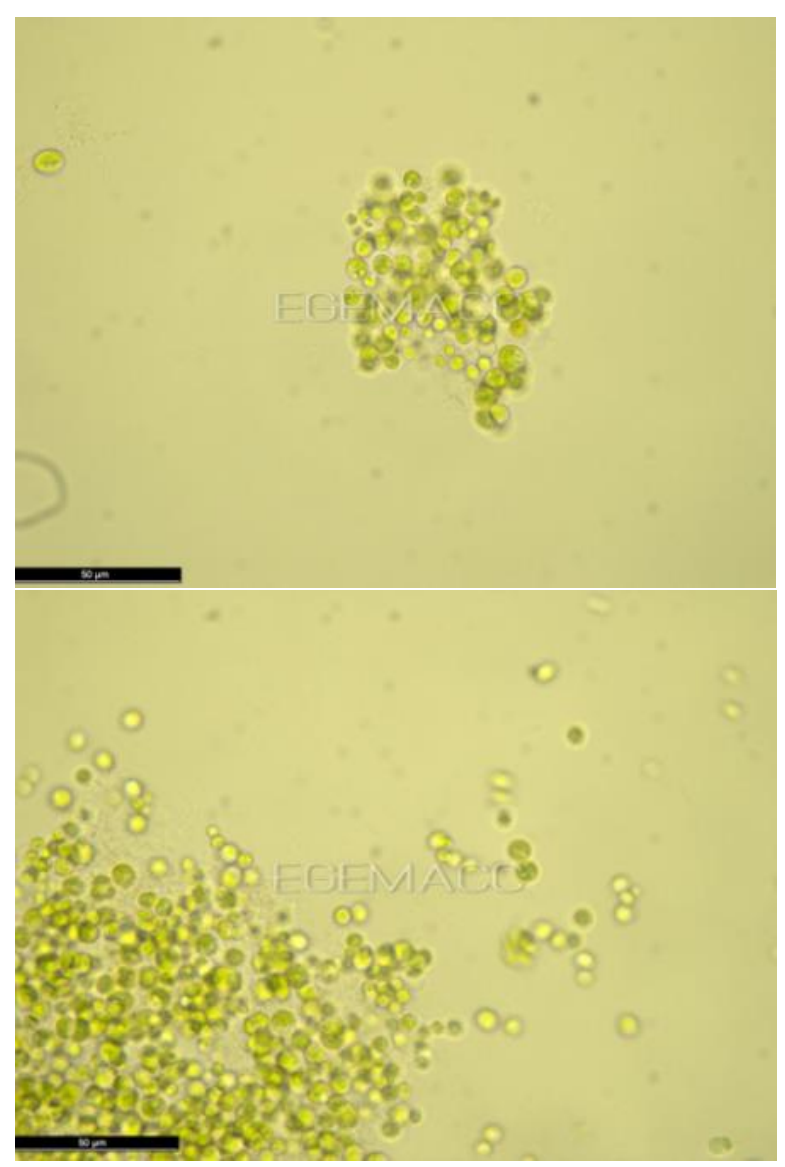

Şekil 1. Chlorella sp.'nin ışık miskoskobu görüntüsü $60 \mathrm{X}$ Figure 1. Light microscope image of Chlorella sp. 60X

Chlorophyta üyelerinin morfolojik olarak birbirine çok benzemesi sebebiyle moleküler olarak tanılamayı da zorunlu kılmıştır. Les Algues D'eau Douce, Initiation à la systématique (Bourrelly 1966/70) mikroalg kataloğu yardımıyla 1şık mikroskobuyla morfolojik olarak Chlorella sp. Beyerinck [Beijerinck], 1890 olduğu tespit edilen 
türün (Şekil 1) DNA's1 ZRFungal/Bacterial DNA Kiti ile izole edilmiştir (Şekil 2).

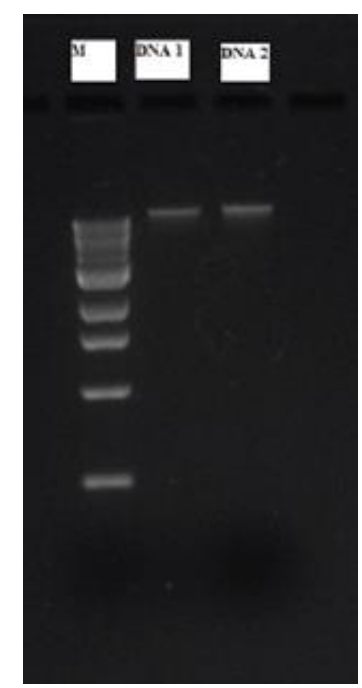

Şekil 2. Chlorella sp.' nın elde edilen DNA' sının agoroz jel üzerindeki görüntüsü Marker (M) $1 \mathrm{~kb}$ DNA ladder (10,0 kb, $8 \mathrm{~kb}, 6,0 \mathrm{~kb}, 5,0 \mathrm{~kb}, 4,0 \mathrm{~kb}, 3,0$ $\mathrm{kb}, 2,0 \mathrm{~kb}, 1,5 \mathrm{~kb}, 1,0 \mathrm{~kb}$ ve $0,5 \mathrm{~kb}$ ); 1(a)-2(b)

Figure 2. The image of DNA obtained from Chlorella $s p$. on agarose gel Marker (M) $1 \mathrm{~kb}$ DNA ladder $(10.0 \mathrm{~kb}, 8 \mathrm{~kb}, 6.0 \mathrm{~kb}, 5.0 \mathrm{~kb}, 4.0 \mathrm{~kb}, 3.0 \mathrm{~kb}$, $2.0 \mathrm{~kb}, 1.5 \mathrm{~kb}, 1.0 \mathrm{~kb}$ and $0.5 \mathrm{~kb}$ ); 1 (a) -2 (b)

359 F-781R(a) için bağlanma sicaklığ $62{ }^{\circ} \mathrm{C}$, 359 F-781R(b) için Nanohelix PCR kitinde $65{ }^{\circ} \mathrm{C}$ derece kullanılarak optimizasyonları yapılmıştır.

Şekil 3' de elde edilen PCR sonuçlarına göre 359F-781R(a) primeriyle çoğaltılan DNA silik bir bant oluştururken, 359 F-781R(b) primeriyle çoğaltılan DNA, belirgin bir bantlaşma göstermiştir. PCR da çoğaltılan 18 S rRNA gen bölgesi de Şekil 3 de belirtilmiştir.

Dizi analizi sonuçları NCBI-Blast programına göre;

359F-781R (a) Auxenochlorella protothecoides 16S small subunit ribosomal RNA gene, partial sequence; chloroplast, AY553213.1; türüne maksimum $\% 90$ benzerlik göstermiştir.

359F-781R (b) Chlorella sorokiniana plastid DNA small subunit (16Slike) ribosomal RNA, X65689.1; türüne maksimum $\% 97$ benzerlik göstermiştir.

SSUF-SSUR Chlorella sorokiniana isolate 34-2 18S ribosomal RNA gene, KU948991.1 türüne maksimum \%97,88 benzerlik göstermiştir (Tablo 3).

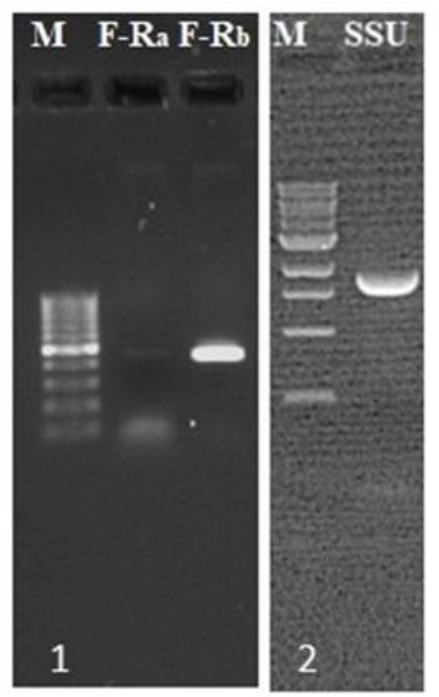

Şekil 3. PCR sonuçları, 1: Marker (M);356F-781R(a) (F-Ra); 356F-781R(b) (F-Rb); 2: Marker (M); SSUFSSUR (SSU)

Figure 3. PCR results, 1: $\operatorname{Marker}(\mathrm{M})$ : 356F-781R (a) (FRa); 356F-781R (b) (F-Rb); 2: Marker (M); SSUF-SSUR (SSU)

Akseniklik kontrolü için yoğunlaşan kültürler "Nutrient Agar" üzerinde temiz bir görüntü oluşturmuştur. Mikroalg dişında bir mikroorganizma üremediği gözlenmiştir (Şekil 4). Ayrıca kültürün optik yoğunluğu (OD), bulanıklığı, $\mathrm{pH}$ değişimi ve Faz-Kontrast mikroskobuyla kontaminasyon içerip içermediği kontrol edilmiştir.

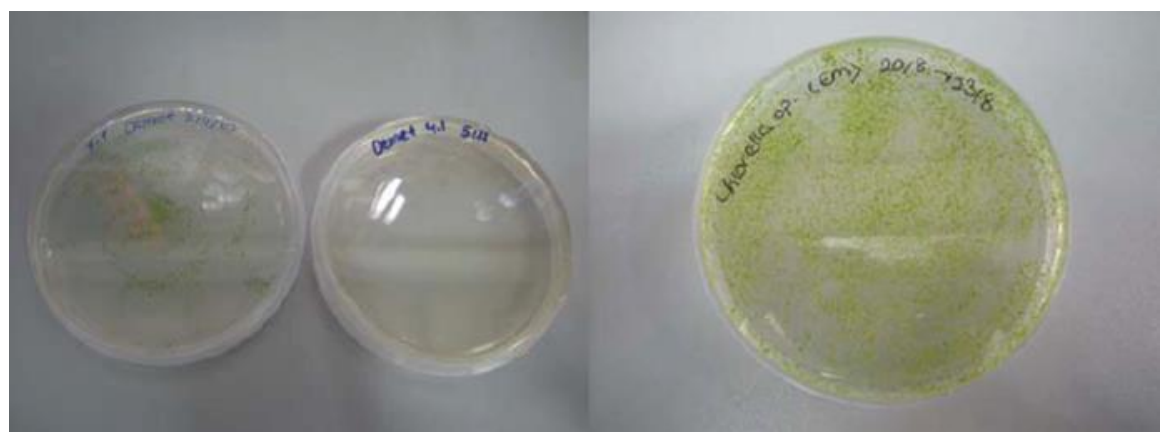

Şekil 4. Aksenik Chlorella sorokiniana kültürü

Figure 4. Axenic Chlorella sorokiniana culture 
Tablo 3. Çoğaltılan gen bölgelerinin NCBI daki nükleotid dizileri ile uyumu (BLAST 2021)

Table 3. Compatibility of the amplified gene regions with the nucleotide sequences in NCBI (BLAST 2021)

\begin{tabular}{|c|c|c|c|c|c|c|}
\hline Tanımlama & $\begin{array}{l}\text { Maksimum } \\
\text { skor }\end{array}$ & Skor & $\begin{array}{l}\text { Sorgulama } \\
\text { k1lifi }\end{array}$ & $\begin{array}{c}\mathrm{E} \\
\text { değeri }\end{array}$ & $\begin{array}{c}\text { Yüzde } \\
\text { tanımlama }\end{array}$ & $\begin{array}{c}\text { Erişim } \\
\text { numaras1 }\end{array}$ \\
\hline $\begin{array}{c}\text { Chlorella sp. EGEMACC40 18S small } \\
\text { subunit ribosomal RNA gene, partial } \\
\text { sequence }\end{array}$ & 1794 & 1794 & 1 & 0.0 & $\% 100,00$ & JQ981943.1 \\
\hline $\begin{array}{l}\text { Chlorella sorokiniana isolate } 34-218 \mathrm{~S} \\
\text { ribosomal RNA gene, partial sequence }\end{array}$ & 1622 & 1622 & 0,96 & 0.0 & $\% 97,88$ & KU948991.1 \\
\hline $\begin{array}{c}\text { Chlorella sp. YACCYB97 18S ribosomal } \\
\text { RNA gene, partial sequence }\end{array}$ & 1607 & 1607 & 0,97 & 0.0 & $\% 97,57$ & MH619545.1 \\
\hline $\begin{array}{l}\text { Pseudochlorella pringsheimii 18S ribosomal } \\
\text { RNA gene, internal transcribed spacer } 1, \\
\text { 5.8S ribosomal RNA gene, internal } \\
\text { transcribed spacer } 2 \text {, and } 28 \text { S ribosomal } \\
\text { RNA gene, complete sequence }\end{array}$ & 1605 & 1605 & 0,97 & 0.0 & $\% 97,47$ & KY364701.1 \\
\hline $\begin{array}{l}\text { Chlorella sp. QUCCCM33 18S ribosomal } \\
\text { RNA gene, partial sequence }\end{array}$ & 1605 & 1605 & 0,97 & 0.0 & $\% 97,47$ & KM985401.1 \\
\hline $\begin{array}{c}\text { Chlorella sorokiniana } \text { strain SAG 211-31 } \\
\text { 18S ribosomal RNA gene, complete } \\
\text { sequence }\end{array}$ & 1605 & 1605 & 0,97 & 0.0 & $\% 97,47$ & KF673387.1 \\
\hline $\begin{array}{l}\text { Chlorella sp. ZJU0209 18S ribosomal RNA } \\
\text { gene, partial sequence }\end{array}$ & 1605 & 1605 & 0,97 & 0.0 & $\% 97,47$ & JX097061.1 \\
\hline $\begin{array}{c}\text { Chlorella sorokiniana 18S rRNA gene, } \\
\text { strain Prag A14 }\end{array}$ & 1605 & 1605 & 0,97 & 0.0 & $\% 97,47$ & X74001.1 \\
\hline $\begin{array}{l}\text { Chlorella sorokiniana } \text { strain Icheon } 418 \mathrm{~S} \\
\text { ribosomal RNA gene, partial sequence }\end{array}$ & 1604 & 1604 & 0,97 & 0.0 & $\% 97,47$ & KF864476.1 \\
\hline
\end{tabular}

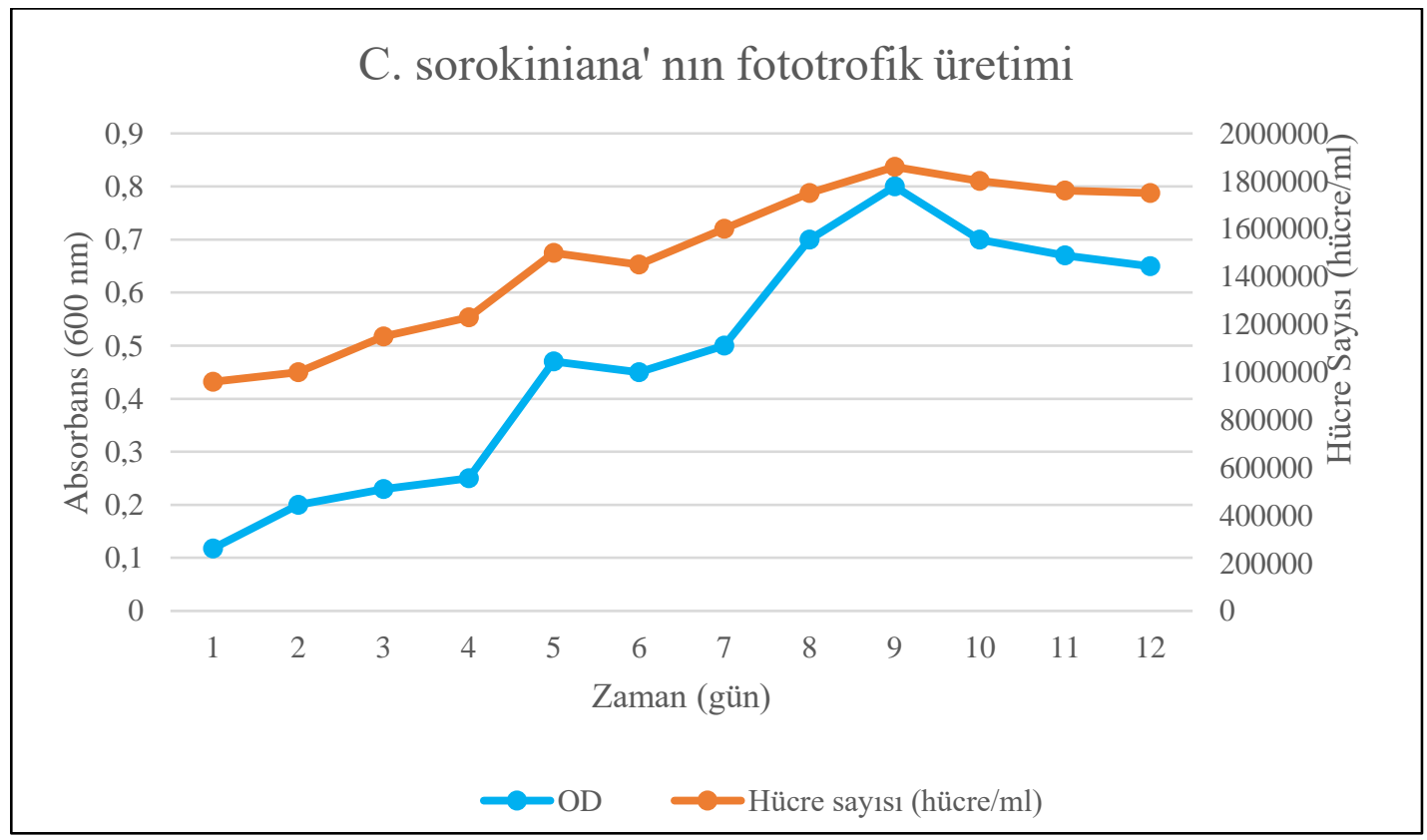

Şekil 5. Chlorella sorokiniana' nın 12 günlük fototrofik koşullar altında optik yoğunluk ve hücre sayısı ölçüm sonuçları Figure 5. Optical density and cell number measurement results of Chlorella sorokiniana under 12-day phototrophic conditions 


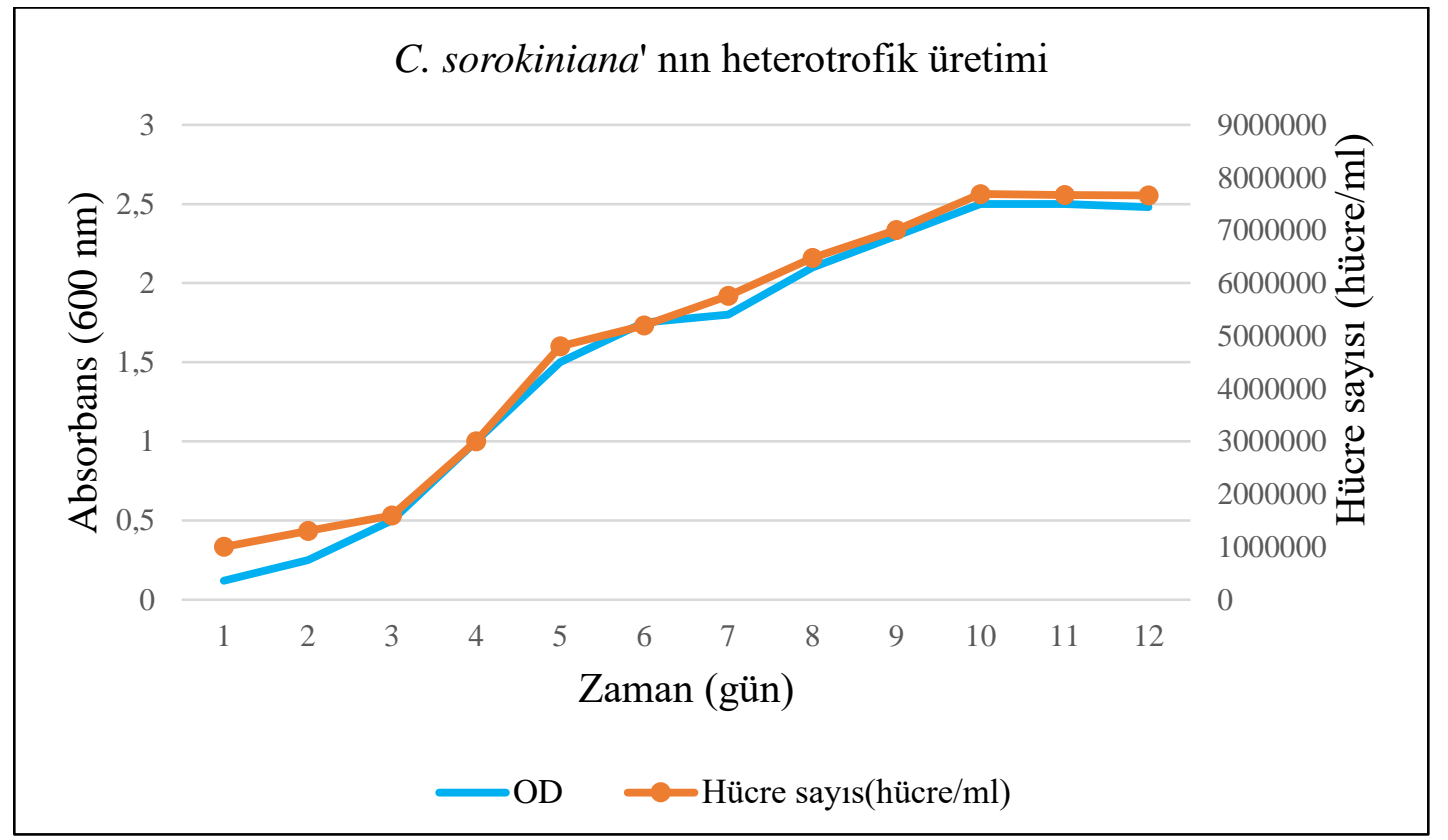

Şekil 6. Chlorella sorokiniana' nın 12 günlük heterotrofik koşullar altında optik yoğunluk ve hücre sayısı ölçüm sonuçları

Figure 6. Optical density and cell number measurement results of Chlorella sorokiniana under 12-day heterotrophic conditions

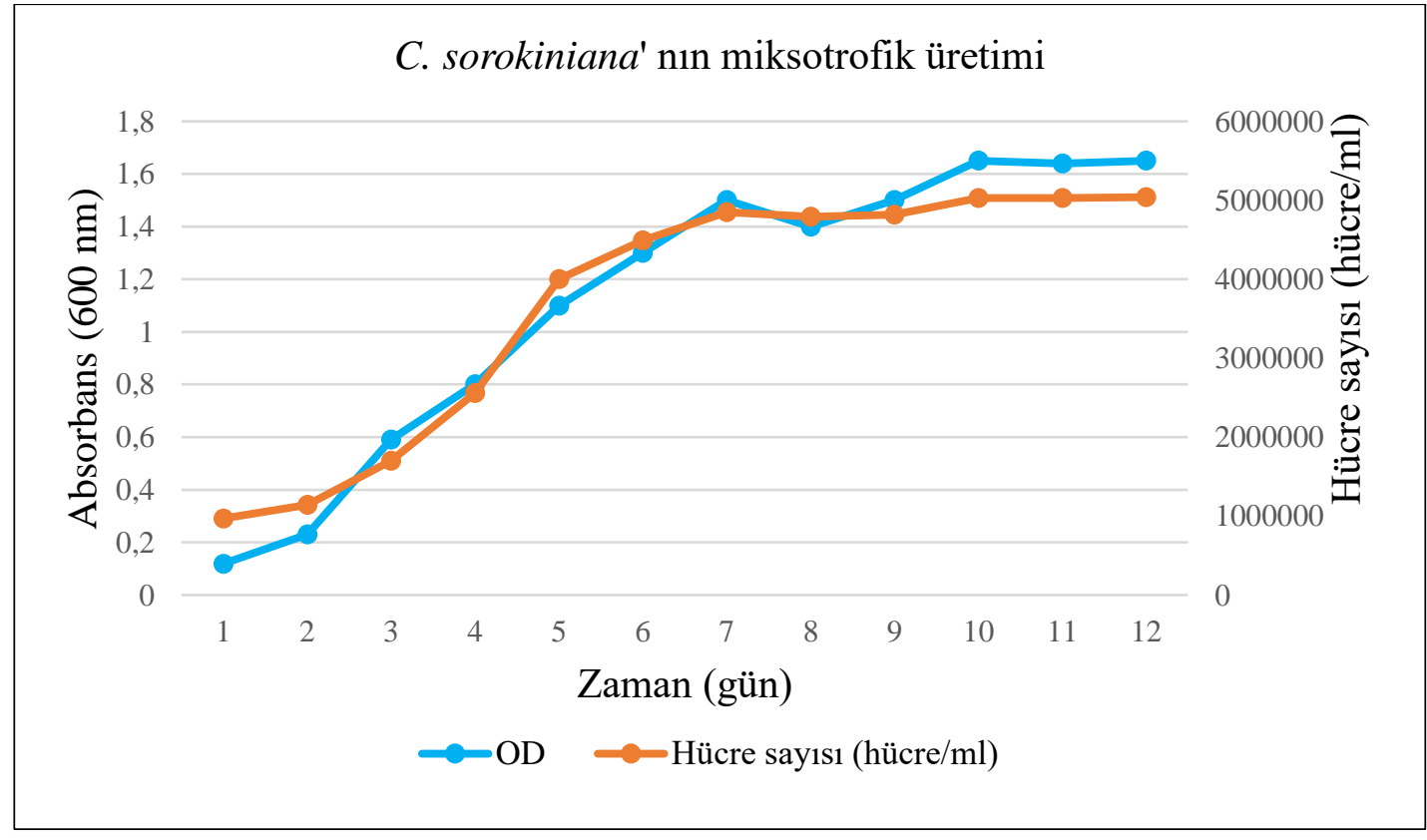

Şekil 7. Chlorella sorokiniana' nın 12 günlük miksotrofik koşullar altında optik yoğunluk ve hücre sayısı ölçüm sonuçları

Figure 7. Optical density and cell number measurement results of Chlorella sorokiniana under 12-day myxotrophic conditions

Pigment farkından dolayı OD’nin birbiri ile karşılaştırılamayacağı düşünülürse biyokütle artışı esas alınmıştır. 12 günlük deney süresince Şekil 5, 6 ve 7'de gösterildiği gibi $C$. sorokiniana' nın hücre sayısı başlangıçtaki hücre sayısına göre fototrofik üretimde yaklaşık 2 kat, heterotrofik üretimde 7,5 kat ve miksotrofik üretimde ise 5,2 kat artmıştır. $\mathrm{Bu}$ üç üretim şekline göre $C$. sorokiniana'nın spesifik büyüme hızı ve ikilenme süresi Tablo 4' te verilmişsir.

C. sorokiniana fototrofik, heterotrofik ve miksotrofik üretim açısından değerlendirildiğinde maksimum büyümenin 8 . gün olduğu bulunmuştur. Aksenik C. sorokiniana' nın farklı üretim yöntemleri karşılaştırıldığında en iyi üretim yönteminin (Şekil 6) heterotrofik üretim yönteminde olduğu belirlenmiştir. 
Tablo 4. Fototrofik, miksotrofik ve heterotrofik üretimi yapılan $C$. sorokiniana'nın spesifik büyüme hızı ( $\mu$ değeri) ve ikilenme süreleri

Table 4. Specific growth rate ( $\mu$ value) and doubling times of $C$. sorokiniana produced under phototrophic, myxotrophic and heterotrophic conditions

\begin{tabular}{lcc}
\hline & Spesifik büyüme hızı (gün $\left.{ }^{-\mathbf{1}}\right)$ & İkilenme süresi (gün) \\
\hline Fototrofik üretim & 0,069 & 10,05 \\
\hline Miksotrofik üretim & 0,108 & 6,93 \\
\hline Heterotrofik üretim & 0,247 & 2,56 \\
\hline
\end{tabular}

\section{Tartışma ve Sonuç}

Son yıllarda yenilenebilir enerji kaynaklarına ve ekonomik üretim yöntemlerine olan ilgi artmıştır. Alglerin bu enerji kaynakları arasındaki yerini alma nedeni ise hızlı büyüme özelliğine sahip olmaları, ortam koşullarındaki değişimlere dayanıklı ve toleranslı olmaları sayılabilir. Mikroalgler genelde fotosentetik organizmalar olarak değerlendirilir. Ancak yapılan çalışmalar çoğu türün heterotrofik ve miksotrofik büyüme yeteneği olduğunu göstermiştir (Droop 1974). Ayrica bu heterotrofik türler neredeyse alglerin bütün taksonomik sınıflarında bulunurlar. Geçtiğimiz elli yıl içerisinde geliştirilen fermantasyon teknolojisi ile büyük miktarlarda maya ve bakterinin endüstriyel üretimi yapilabilmektedir ve bu teknoloji ile heterotrofik algal üretim kolayca yapılabilir. Diğer mikroorganizmalar için kullanılan fermantasyon tankları aynı zamanda heterotrofik alg üretimi içinde uygundur. Buna ek olarak hücrenin büyümesi ve biyokimyasal içeriğini etkileyen bazı parametreler de kontrol edilebilir. Ayrıca verimliliği arttırma maliyetleri azaltma metotları ile ilgili zengin bir endüstriyel mikrobiyolojik bilgi kaynağı da vardır.

Bulut (2009) tarafindan Chlorella vulgaris' in fototrofik üretimi sonucu elde edilen maksimum kuru ağırlık 0,19 g. $\mathrm{L}^{-1}$ olarak belirlenmiştir. Başka bir çalışmaya göre heterotrofik olarak üretilen; Chlorella sorokiniana' dan $1 \mathrm{~g} \mathrm{~L}^{-1} \mathrm{~h}^{-1}$, Nitzschia alba' dan $0,8 \mathrm{~g} \mathrm{~L}^{-1} \mathrm{~h}^{-1}$, Arhtrospira sp.' dan $1,2 \mathrm{~g}$ $\mathrm{L}^{-1} \mathrm{~h}^{-1}$ biyokütle elde edilmiştir (AlgaePARC 2021). Kim vd. (2013) tarafından yapılan bir çalışmada C. sorokiniana' nın spesifik büyüme hızı fototrofik, heterotrofik ve miksotrofik koşullarda sirasıyla 0,24 gün $^{-1}, 0,53$ gün $^{-1}$ ve 0,44 gün $^{-1}$ olarak bildirilmiştir. Ayrıca aynı çalışma sonuçlarına göre C. sorokiniana' nın nitrojen ve fosfor giderim hızı heterotrofik üretimin fototrofik üretimden iki kat daha yüksek olduğu görülmüştür. Heterotrofik mikroalglerin organik substratları ve besinleri giderim hızı yüksek olduğu için ileri atık su arıtımında iyi bir seçenek olabilir. Baytut vd. (2014) Türkiye' nin alg florasında C. sorokiniana Shihira \& Kraus (A102) ilk kez 2014 yılında kayıt altına almıştır. C.sorokiniana tatlı sularda yaşayan bir yeşil mikroalg olmasına (Kim vd. 2016) rağmen Chen vd. (2013) yerel izolatları olan C. sorokiniana CY1 türünü \%20 deniz suyu ortamında yetiştirerek yağ miktarını $\% 61$ ve biyokütle miktarını ise $3 \mathrm{~g} / \mathrm{L}$ olarak belirlemiştir.

Sonuç olarak, bu çalışma ile ülkemiz sularında yayılış gösteren bir yerel mikroalg izole edilmiş, moleküler yöntemlerle tanımlanmış laboratuvar koşullarında kültürü yapılmıştır. NCBI gen bankasına kayıt ettirilen mikroalg için JQ981943.1 aksesyon numarası alınmıştır. Tür tayini yapılan mikroalg örneği Ege Üniversitesi Mikroalg Kültür Koleksiyonu' na (EGE-MACC 40) eklenmiştir. $C$. sorokiniana biyokütle verimliliği açısından değerlendirilerek bu tür için üç üretim şeklinden en iyi sonuç heterotrofik koşullar altında sağlanabilmiştir. Bu çalışma ile elde edilen verilerin de ileride yapılması planlanan büyük ölçekli üretime temel oluşturabilecek ön çalışma niteliği taşıdığ 1 düşünülmektedir.

\section{Teşekkür}

$\mathrm{Bu}$ çalışmayı destekleyen Ege ÜniversitesiBiyomühendislik Bölümü Algal Biyoteknoloji Laboratuvar ekibine ve Doç. Dr. Müge İşleten Hoşoğluna teşekkür ederim.

\section{Kaynaklar}

Abreu AP, Fernandes B, Vicente AA, Teixeira J, Dragone G. 2012. Mixotrophic cultivation of Chlorella vulgaris using industrial dairy waste as organic carbon source. Bioresour Technol. 118:6166.

doi: 10.1016/j.biortech.2012.05.055

AlgaeBase. 2021. [Erişim tarihi: 09 Mar 2021]. Erişim Adresi: https://www.algaebase.org/search/species/det ail/?species_id=r7b5b5e3003154f99

AlgaePARC. 2021. Wageningen University\&Research, [Erişim tarihi: 09 Mar 2021]. Erişim Adresi: http://www.algaeparc.com/news

Baytut Ö, Gürkanli CT, Gönülol A, Özkoç I. 2014. Molecular phylogeny of Chlorella-related chlorophytes (Chlorophyta) from Anatolian freshwaters of Turkey. Turkish Journal of Botany. 38(3): 600-607.

doi:10.3906/bot-1304-32 
Becker EW. 1995. Microalgae biotechnology and microbiology. Cambridge University Press. p. 293. doi.org/10.1002/jctb.280470214

Becker EW. 2007. Microalgae as a source of protein. Biotechnol Adv. 25(2):207-210. doi: 10.1016/j.biotechadv.2006.11.002

BLAST. 2021. [Erişim tarihi: 09 Mar 2021]. Erişim Adresi:https://blast.ncbi.nlm.nih.gov/Blast.cgi\#alnHd r_395406506

Borowitzka MA. 1992. Algal biotechnology products and process-Matching science and economics. J. appl. Phycol. 4: 267-279.

Bourrelly P. 1966/1970. "Les Algues D'eau Douce. Initiation à la systématique". Tome I: Les Algues vertes. Tome II: Chrysophyées, Xanthophycées et Diatomées. Tome III: Eugléniens, Péridiniens, Algues rouges et Algues bleues. - Avec $118+115+$ 137 planches, $13+22+14$ figures, $512+440+544$ pp. Paris: Editions N. Boubée \& Cie. doi.org/10.1002/iroh.19740590219

Boutte C, Grubisic S, Balthasart P and Wilmotte A. 2006. Testing of primers for the study of cyanobacterial molecular diversity by DGGE. Journal of Microbiological Methods. 65:542-550. doi: 10.1016/j.mimet.2005.09.017

Bulut, Y. 2009. Chlorella'da (Clorophyceae) yağ miktarının arttırma olanaklarının araştırılması. [Yüksek Lisans Tezi]. Çukurova Üniversitesi. 62 s.

Chen F. 1996. High cell density culture of microalgae in heterotrophic growth. Trends in Biotechnology. $14: 421-426$. doi: 10.1016/0167-7799(96)10060-3

Chen CY, Yeh KL, Aisyah R, Lee DJ, Chang JS. 2011. Cultivation, photobioreactor design and harvesting of microalgae for biodiesel production: A critical review. Bioresour Technol. 102(1):71-81.

doi: 10.1016/j.biortech.2010.06.159

Chen CY, Chang JS, Chang HY, Chen TY, Wu JH, Lee WL. 2013. Enhancing microalgal oil/lipid production from Chlorella sorokiniana CY1 using deep-sea water supplemented cultivation medium. Biochemical Engineering Journal. 77:74-81. doi:10.1016/j.bej.2013.05.009

Chojnacka K, Marquez-Rocha FJ. 2004. Kinetic and stoichiometric relationships of the energy and carbon metabolism in the culture of microalgae. Biotechnology. 3:21-34. doi:10.3923/biotech.2004.21.34

Droop MR. 1974. Heterotrophy of carbon. In: Stewart WDP, editor. Algal Physiology and Biochemistry. Oxford (England). Blackwell Scientific Publ. p. 530-559.

Elcik H, Çakmakcı M. 2017. Mikroalg üretimi ve mikroalglerden biyoyakıt eldesi. Journal of the Faculty of Engineering and Architecture of Gazi University. 32(3):795-820. doi: 10.17341 /gazimmfd.337627

Güner $H$ ve Aysel V. 1991. Tohumsuz Bitkiler Sistematiği, Ege Üniversitesi Fen Fakültesi Kitaplar Serisi No:108
Hariskos I, Posten C. 2014. Biorefinery of microalgae opportunities and constraints for different production scenarios. Biotechnol J. 9(6):739-752.

doi: 10.1002/biot.201300142

Kim BH, Ramanan R, Kang Z, Cho DH, Oh HM, Kim HS. 2016. Chlorella sorokiniana HS1, a novel freshwater green algal strain, grows and hyperaccumulates lipid droplets in seawater salinity. Biomass and Bioenergy. 85:300-305. doi:10.1016/j.biombioe.2015.12.026

Kim S, Park JE, Cho YB, Hwang SJ. 2013. Growth rate, organic carbon and nutrient removal rates of Chlorella sorokiniana in autotrophic, heterotrophic and mixotrophic conditions. Bioresour Technol. 144:8-13. doi: 10.1016/j.biortech.2013.06.068

Kobayashi M, Kakizono T, Yamaguchi K, Nishio N, Nagai S. 1992. Growth and astaxanthin formation of Haematococcus pluvialis in heterotrophic and mixotrophic conditions. J Ferment Bioeng. 74 (1):17-20. doi: 10.1016/0922-338X(92)90261-R

Lee YK. 2001. Microalgal mass culture systems and methods: their limitation and potantial. Journal of Applied Phyycology. 13:307-315. doi: 10.1023/A:1017560006941

Liu J, Huang J, Sun Z, Zhong Y, Jiang Y, Chen F. 2011. Differential lipid and fatty acid profiles of photoautotrophic and heterotrophic Chlorella zofingiensis: assessment of algal oils for biodiesel production. Bioresource Technology. 102:106-110. doi: 10.1016/j.biortech.2010.06.017

McLachlan J. 1973. Growth media marine, In Stein, J.R (ed.) Culture Methods\&Growth Measurements. Cambridge University Press. p. 25-51.

Marquez FJ, Sasaki K, Kakizono T, Nishio N, Nagai S. 1993. Growth characteristics of Spirulina platensis in mixotrophic and heterotrophic conditions. Journal of Fermentation and Bioengineering. 76:408-410. doi: 10.1016/0922-338X(93)90034-6

Miao X, Wu Q. 2004. High yield bio-oil production from fast pyrolysis by metabolic controlling of Chlorella protothecoides. J Biotechnol. 110(1):85-93. doi: 10.1016/j.jbiotec.2004.01.013

Mitra D, van Leeuwen J, Lamsal B. 2012. Heterotrophic/mixotrophic cultivation of oleaginous Chlorella vulgaris on industrial co-products. Algal Res. 1(1):40-48. doi: 10.1016/j.algal.2012.03.002

Nübel U, Garcia- Pichel F and Muyzer G. 1997. PCR Primers to amplify $16 \mathrm{~S}$ rDNA Genes from cyanobacteria. Applied and Environmental Microbiology. 63(8):3327-3332. doi: 10.1128/AEM.63.8.3327-3332.1997

Pragya N, Pandey KK, Sahoo PK. 2013. A review on harvesting, oil extraction and biofuels production technologies from microalgae. Renewable Sustainable Energy Rev. 24:159-171. doi: 10.1016/j.rser.2013.03.034

Provasoli L. 1963. Growing marine seaweeds. In: De 
Virville AD and Feldmann J (Eds.) Proceedings of the Fourth International Seaweed Symposium. Pergamon Press. Oxford. p. 9-17.

Provasoli L. 1968. Media and prospects for the cultivation of marine algae. In: Watanabe $\mathrm{H}$, Hattori A, (eds.). Cultures and collections of algae. Proceedings US-Japan Conference. Hakone: Japanese Society of Plant Physiology. p. 63-75.

Sasson A. 1997. Microalgal biotechnologies: Recent developments and prospects for developing countries. Biotec Publication. 1:76.

Sukatar A. 2002. Algal culture methods (in Turkish). Ege Üni Fen Fak. Kitapları Serisi No:184. s.104.

Yeh KL, Chang JS, Chen WM. 2010. Effect of light supply and carbon source on cell growth and cellular composition of a newly isolated microalga Chlorella vulgaris ESP-31.Eng Life Sci. 10(3):201-208. doi: 10.1002/elsc.200900116

Yıldırım A, Demirel Z, İşleten-Hoşoğlu M, Akgün İH,
Hatipoğlu-Uslu S, Conk-Dalay M. 2014. Carotenoid and fatty acid compositions of an indigenous Ettlia texensis isolate (Chlorophyceae) under phototrophic and mixotrophic conditions. Applied Biochemistry and Biotechnology. 172(3): 1307-1319. doi: 10.1007/s12010-013-0599-y

Zhang H, Wang W, Li Y, Yang W, Shen G. 2011. Mixotrophic cultivation of Botryococcus braunii. Biomass and Bioenergy 35:1710-1715.

doi: 10.1016/j.biombioe.2011.01.002

Zhu L. 2015. Biorefinery as a promising approach to promote microalgae industry: An innovative framework. Renewable Sustainable Energy Rev. 41:1376-1384.

doi: 10.1016/j.rser.2014.09.040

Wang H, Xiong H, Hui Z, Zeng X. 2012. Mixotrophic cultivation of Chlorella pyrenoidosa with diluted primary piggery wastewater to produce lipids. Bioresour Technol. 104:215-220. 